\title{
O ECO MATERIALIZADO: CONSIDERAÇÕES SOBRE O TEOR PROFÉTICO DA CANÇÃO DE SIRUIZ
}

\author{
Patrícia Tavares da Cunha Fuza \\ Ederson Vertuan
}

Como os sonhos esfingéticos que acometem José, filho de Jacó, na passagem bíblica, também Guimarães Rosa, em seu Grande sertão: veredas (1956), "instaura a completa desordem no coração de Riobaldo" (REINALDO, 2005) a partir de uma canção entoada por alguém sem rosto, quase ausente, uma voz imaterial que ecoa pela noite e passa a pulsar em Riobaldo durante toda a sua jornada. A canção de Siruiz trata da busca do conhecimento de si e do outro através da decifração de um enigma que engloba o "redemunho" da própria existência de Riobaldo. Ao ouvi-la, ele tem sua "iniciação", prova do fruto proibido, mergulha nos "remansos" do São Francisco, largando a pacata vida abastada ao lado do padrinho Selorico Mendes para lançar-se ao seu destino, à aventura da vida de jagunço e do amor proibido por Diadorim, a "moça virgem". Envereda-se, a partir de então, no grande sertão que é o mundo. O caminho do jovem Riobaldo está traçado e nem ele mesmo sabe. Assim como não pode fugir da força arrebatadora daquela canção, também é impossível fugir de seu destino.

\section{PALAVRAS-CHAVE:}

Guimarães Rosa; canção de Siruiz; profecia.

"A vida é muito discordada. Tem partes. Tem artes. Tem as neblinas de Siruiz. Tem as caras todas do Cão, e as vertentes do viver."

Grande Sertão: Veredas

A conversão de energia em matéria, apesar de uma realidade Física1', parece ainda não ter servido de argumento para defender a hipotética noção do sobrenatural enquanto responsável pelo surgimento do mundo material. Desse modo, também em Grande sertão: veredas (1956) há uma forte relação entre material e imaterial ${ }^{2}$, desenvolvendo-se por vias tão complexas quanto a proposição acima. Uma canção imaterial ${ }^{3}$, uma voz entoada numa "madrugada dobrada inteira" (p.103), torna-se o elo profético entre Riobaldo e seu destino, marcado por forças desconhecidas, que esta mesma canção profetiza. Por conseguinte,

\footnotetext{
1 Em laboratório, a energia de um fóton de raios gama pode ser convertida, facilmente, em duas partículas muito pequenas de matéria.

2 Por material, entenda-se concreto, mundano. Imaterial, nesse estudo, refere-se à energia sobrenatural ou àquilo que com ela mantém estreita relação.

3 A música, o som, obviamente, são inerentes ao mundo físico, tanto no que diz respeito à sua fonte quanto à sua propagação. Este estudo, no entanto, os considera imateriais, pois se atém apenas às suas propriedades energéticas e sua consequente relação com forças supranaturais. Muitos consideram o som como uma energia, teoria essa que se confirma ao se considerar os toques ritualísticos usados por algumas religiões para atrair entidades diversas.
} 


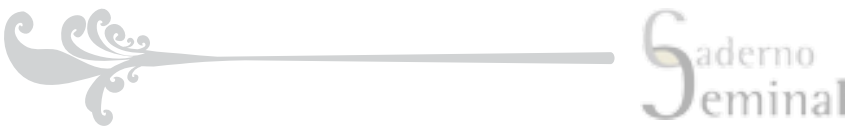

a energia etérea, adquirida por Riobaldo através do pacto sobrenatural, revelase em eventos e circunstâncias que o favorecem. Nesse entremeio, a canção tão familiar toma forma, materializa-se no cavalo Siruiz, símbolo da profecia antes lançada e do contrato etéreo firmado com o desconhecido.

Muitos pesquisadores defendem a ideia da canção de Siruiz enquanto uma profecia $^{4}$, similar a outros tantos enigmas existentes na história da literatura e da civilização. Imagens vagas que povoam sonhos premonitórios, sons que evocam situações passadas e futuras, frases aparentemente desconexas que escamoteiam revelações profundas, "neblinas" capazes de revelar outras verdades, outras "matérias-vertentes", outras veredas. A história da humanidade, em suas mais variadas expressões, sejam elas ficcionais ou não, apresenta inúmeras passagens em que indivíduos testemunham situações de natureza mística e metafísica, nas quais enigmas Ihes são propostos com o intuito de, por meio de sua resposta, revelar informações sobre o passado e o futuro. Tais revelações

podem ser as profecias, maldições, prenúncios, expectativas, dúvidas, planos, avisos, pressentimentos, fé e aspirações. O anúncio indica, para o leitor, uma experiência iminente que um personagem poderá ter ou não... aponta o que vem adiante, usando as intenções dos personagens de obter ou realizar um evento futuro (ABEL, 2003, p. 204).

Muitos episódios, de épocas e fontes diversas, constituem exemplos dessas parábolas enigmáticas propostas a figuras humanas ou míticas ilustres. Em Édipo Rei, de Sófocles, o personagem principal recorre ao auxílio de entidades adivinhatórias, como o oráculo de Delfos e a Esfinge, a fim de desvendar sua origem e seu destino. Na Teogonia, de Hesíodo, também as musas afirmam que, quando querem, sabem "proclamar muitas verdades". Ainda tratandose da tragédia, Orpheu, após ter seu corpo despedaçado pelas Mênades e lançado ao rio Hebro, tem a cabeça encontrada na Jônia por um pescador, que a enterra. Naquele lugar, é erigido um templo, ao qual os moradores e viajantes passam a recorrer em busca de respostas para suas ações futuras.

Na Antiguidade, um sonho esfingético que nos legou a expressão "vacas magras e vacas gordas" como símbolo de penúria e abundância, é o do faraó do Egito, referido na Bíblia, no capítulo 41 do livro de Gênesis, que foi interpretado por José, filho de Jacó, passando à História como José, governador do Egito. No hinduísmo, praticado na Índia, o quarto livro sagrado, chamado Atarva Veda (veda = conhecimento, tradição), fonte de inspiração espiritual presumivelmente escrito no século 25 a.C, também contém um capítulo sobre presságios oníricos.

No entanto, todos esses presságios, sejam eles como forem, não revelam claramente o conteúdo de suas verdades. Exigem a experiência para que suas mensagens sejam compreendidas (REINALDO, 2005). Recorrentemente, vemos situações emblemáticas, muitas vezes decifradas apenas no momento derradeiro 


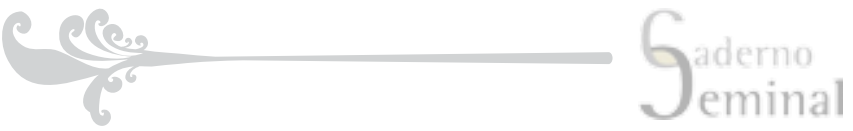

da existência. São respostas enevoadas, subjetivas, intimistas, prostradas diante dos olhos, vistas, mas não enxergadas no seu sentido mais stricto.

Nos três primeiros exemplos citados, embora os presságios sejam enigmáticos, enevoados, há a presença da materialidade, já que os veículos usados para a transmissão de tais enigmas e responsáveis pelas adivinhações são seres humanos ou míticos, como a Esfinge e as sacerdotisas de Delfos. No entanto, como os sonhos que acometem José na passagem bíblica, Guimarães Rosa, em seu Grande sertão: veredas, "instaura a completa desordem no coração de Riobaldo" (REINALDO, 2005) a partir de uma canção entoada por alguém sem rosto, quase ausente, uma voz imaterial que ecoa pela noite e passa a pulsar em Riobaldo durante toda a sua jornada.

Certa noite, quando o bando de Joca Ramiro se instala na propriedade do padrinho Selorico Mendes, Riobaldo, já impressionado pela visão dos capangas de Joca Ramiro - dentre eles o Hermógenes, seu futuro inimigo -, sente-se tocado por uma canção entoada pelo desconhecido violeiro-jagunço Siruiz. Quando os homens, "perto duns cem", acomodam-se na fazenda de Selorico, "num fechado, mato caapuão", seguidos pelos olhos atentos do moleque Riobaldo, "um falou mais alto, aquilo era bonito e sem tino: - 'Siruiz, cadê a moça virgem?'” (p. 101). Nesse momento, "algum, aquele Siruiz, cantou, palavras diversas", para Riobaldo, a "toada toda estranha":

\footnotetext{
Urubú é vila alta,

mais idosa do sertão:

padroeira, minha vida

vim de lá, volto mais não...

Vim de lá, volto mais não?...

Corro os dias nesses verdes,

meu boi mocho baetão:

burití - água azulada,

carnaúba - sal do chão...

Remanso de rio largo,

viola da solidão:

quando vou p'ra dar batalha

convido meu coração...

(ROSA, 1986, p. 101)
}

Instantaneamente, Riobaldo se sente tocado e intrigado com aquela canção. Ela ecoa dentro dele durante toda a narrativa, mas mantém-se emblemática, como uma espécie de canto esfingético, uma neblina que, contrariamente a Édipo, é incapaz de decifrar.

O que eu guardo no giro da memória é aquela madrugada dobrada inteira: os cavaleiros no sombrio amontoados, feito bichos e árvores, o refinfim do orvalho, a estrela d'alva, os grilinhos do campo, o pisar dos cavalos e a canção de Siruiz. Algum significado isso tem? (ROSA, 1986, p. 103) 
Marcado profundamente por essa canção, Riobaldo, no entanto, não deixa de admitir que a considera "estúrdia". E não é descabido afirmar que o leitor de Grande sertão: veredas, o mais das vezes, partilha da mesma opinião.

Embora a canção de Siruiz tenha como base uma métrica tradicional simples ${ }^{5}$, ela nada tem de popular. Uma referência a Dante Alighieri ${ }^{6}$ e os significados ocultos na sonoridade metafórica do poema ${ }^{7}$ não fazem muito para mudar isso. Daí Riobaldo ser o único a ver beleza nos versos, que, de fato, não eram populares entre os demais jagunços ${ }^{8}$. Consequentemente, a canção de Siruiz não pode ser considerada uma canção campesina comum, assim como Riobaldo e sua sina não o foram. Toda a relação da canção com a sugestão do mistério e do oculto vem a servir a outro propósito: a antecipação da relação de Riobaldo com forças desconhecidas.

\section{A propriedade profética da cancão}

A canção de Siruiz trata da busca do conhecimento de si e do outro através da decifração de um enigma que engloba o "redemunho" da própria existência de Riobaldo. Ao ouvi-la, ele tem sua "iniciação", prova do fruto proibido, mergulha nos "remansos" do São Francisco, largando a pacata vida abastada ao lado do padrinho Selorico Mendes para lançar-se ao seu destino, à aventura da vida de jagunço e do amor proibido por Diadorim, a "moça virgem". Enveredase, a partir de então, no grande sertão, que é o mundo. O caminho do jovem Riobaldo está traçado e nem ele mesmo sabe. Assim como não pode fugir da força arrebatadora daquela canção, também é impossível fugir de seu destino.

O canto, a palavra cantada, que a poesia hesiódica considerava "a mais elevada expressão da palavra mítica criadora" (REINALDO, 1998), se junta ao som de seu acompanhamento, a viola, um instrumento imbuído em fantasia e ancestralidade ${ }^{9}$, para compor um par sonoro ideal ao anúncio profético.

O canto, o som da viola e, também, os números que se pode extrair do poema ( 3 quadras; 12 versos; 7 sílabas ${ }^{10}$ ) se reúnem enquanto sinais de uma $5 \quad$ A redondilha menor, preferida do sertanejo.

$6 \quad$ Os versos da canção foram elaborados de forma a esconder seus temas. Por exemplo, Roncari (2001) considera o verso "Urubú é vila alta," que se refere a certa "vila do urubu", como uma paródia do tema inicial da Divina Comédia: "No meio do caminho de nossa vida / Encontrei-me numa selva obscura / Que a estrada reta fora perdida". O pesquisador afirma que "vila do urubu" representa uma metáfora da metáfora "selva obscura". Uma vez que selva assume valor simbólico de "vida terrena", vila assume o lugar de selva (vida terrena) e urubu substitui "obscura", donde se conclui a ideia de "vila do urubu" como metáfora para "vida terrena sombria".

7 O âmbito estilístico dos versos da canção traz consigo sentidos ocultos. O ditongo nasal "-ão", por exemplo, rima que perpassa todo o poema, possui, segundo Nilce Sant'Anna Martins, dois níveis de propriedades sonoras. $O$ primeiro diz respeito a sons velados, isto é, sons ocultos, escondidos, encobertos, sem timbre puro. O segundo diz respeito à sua capacidade de expressar alongamento: seu som prolongado serve tanto para evocar distância quanto lentidão, moleza e melancolia . O som alongado, assim, serve como alusão à escuridão e aos mistérios da selva/vida de Riobaldo, bem como ao longo tempo durante o qual a travessia de sua sina é realizada.

8 No entanto, a afirmação de Riobaldo sobre ser o único interessado na canção contrasta com um episódio anterior em que os jagunços, aparentemente familiarizados com a canção, pedem, com entusiasmo, para que Siruiz entoe a "canção da moca virgem".

9 Segundo Correa (2000), o universo da viola implica toques ancestrais e versos marcados pela tradição, o que faz do instrumento um auxiliar na expressão da alma. Para os violeiros antigos, apenas quem possui um dom divino é capaz de dominar o instrumento, a não ser que o indivíduo que não recebeu tal bênção recorra a um pacto. 10 Números com sentidos simbólicos diversos, mas que tem em comum a associação a ideias de totalidade e 


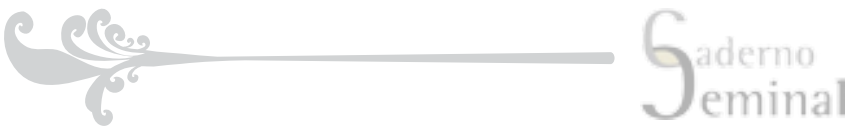

sacralidade profética que prenuncia, quase em tom sublime, todo o ciclo da sina de Riobaldo. São esses os elementos que relacionam a canção de Siruiz com o profético e o sagrado. E que, além disso, constituem pano de fundo ideal para a condição mágica do envolvimento de Riobaldo com forças ocultas que, acionadas a seu favor, serão materializadas em episódios e elementos narrados ao longo do livro, assim como no próprio cavalo.

Os versos entoados pelo jagunço Siruiz perseguem Riobaldo durante sua peregrinação pelas veredas do sertão e de seus próprios medos, desejos, frustrações e lembranças. Siruiz não tem rosto, carne, matéria. É apenas uma voz que ecoa no meio da madrugada, uma névoa... que somente se materializará a partir da posse do novo cavalo, a quem Riobaldo nomeia Siruiz, ao invés de Barzabú.

\section{O insólito em Siruiz}

A canção não vem a ser apenas uma profecia: ela também revela uma face soturna, imaterial enquanto proferida por uma presença na ausência; porém material, na medida em que se faz palpável na tomada de posse, por parte de Riobaldo, das "rédeas" de seu próprio destino através do cavalo batizado de Siruiz.

No transcorrer da narrativa, Riobaldo questiona a existência do Demo e sua real influência nas ações humanas. Ouve de seus companheiros que Hermógenes é pactário e, seduzido pela possibilidade de tornar-se tão ou mais poderoso que o jagunço, abandonando suas dúvidas e receios, Riobaldo decide fazer o pacto. Numa encruzilhada das Veredas Mortas, à meia-noite, invoca o Tinhoso, mas acredita não ter resposta. No entanto, volta do vale com a coragem e a ousadia que sempre almejou. Ao encontrar-se com o bando, outro acontecimento insólito: os cavalos, ao verem Riobaldo, agitam-se.

\footnotetext{
A sua influência no meio ambiente foi muito sentida, principalmente, pelos cavalos- antenas do mundo das trevas. Quando reuniram os cavalos, fez um "rebuliz". Os quadrúpedes viram-no chegar, como não podiam escapulir, "suavam, e já escumavam e retremiam, que com as orelhas apontavam". Riobaldo pulou "para o meio deles: - 'Barzabú! Aquieta, cambada!' E os cavalos se aquietaram (ABEL, 2003, p. 304).
}

Nesse instante, chega seu Habão com um corcel, "gateado formoso" (p. 378) que "chicoteia alto o ar", empinando. Riobaldo grita "- Barzabú!" e o "cavalão lão lão" se acalma. Ao ver que o corcel estranhamente obedece a Riobaldo, seu Habão resolve presenteá-lo com o cavalo. Os outros jagunços sugerem a Riobaldo que chame seu presente de Barzabú. No entanto, como uma tentativa de negar para si o pacto sugerido a pouco, Riobaldo o batiza de cavalo Siruiz.

Com o bem observa Moraes (2001), esse novo cavalo substitui o cavalo morto Padrim Selorico. De acordo com a pesquisadora, a substituição do nome do 


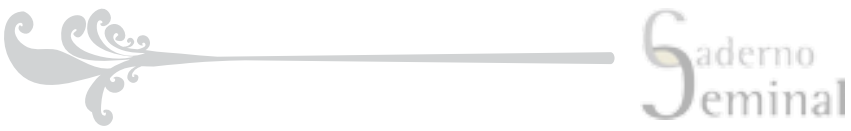

pai-padrinho de Riobaldo, Selorico Mendes, pelo de um desconhecido - o jagunço Siruiz - representa uma metáfora de rompimento com os laços de paternidade-apadrinhamento e de pertencência, para que a posição de Riobaldo enquanto autoridade seja assumida.

No entanto, é importante complementar: é também no plano sobrenatural que o apadrinhamento divino se desfaz, para que, em seu lugar, se instale o auxílio de forças desconhecidas. O nome do novo cavalo de Riobaldo assinala o desligamento de sua anterior condição passiva e subserviente para a de agente, de dono de seu destino e de entrega a tudo o que a canção de Siruiz profetizara. O cavalo com que Habão presenteia Riobaldo representa a primeira insígnia de chefia e de comando que lhe é conferida. Mas essa condição superior, convém lembrar, só é assumida após o pacto.

E essa relação entre o pacto de Riobaldo e o recebimento do novo cavalo Siruiz chama a atenção para uma relação existente entre as quatro faces de um quadrilátero: Riobaldo, seu cavalo, as forças sobrenaturais e a canção de Siruiz.

Com toda a profecia sombria descrita na canção de Siruiz, que já sugeria as trevas, o desvio e a travessia, inclusive, de ordem espiritual ${ }^{11}$, o batismo do cavalo como Siruiz não mostra apenas a união com os laços sobrenaturais. É também uma energia que se materializa e que passa a auxiliar/conduzir Riobaldo em sua nova fase, mediando suas vontades entre dois mundos. Além disso, uma vez que o cavalo representa uma insígnia de poder que veio após o pacto, logo ele marca simbolicamente o contrato sobrenatural feito por Riobaldo. E, assim, fecha-se a relação entre as faces do quadrilátero Riobaldo/canção/pacto/cavalo.

É o lado estranho, sombrio e oculto da canção que acaba se cumprindo com as atitudes de Riobaldo enquanto pactário. Montar em Siruiz significa unir-se intimamente com a canção profética que tanto o intrigara e com seu destino e identidade jagunças. Mas o destino de Riobaldo e o destino descrito na canção de Siruiz se confluem apenas com a ajuda do sobrenatural, quando Riobaldo, ao menos, tem a chance, de estar no controle de sua própria vida.

\section{Pactos e pacto: um contrato sobrenatural REPLETO de brasilidade}

Segundo uma lenda bastante conhecida por folcloristas portugueses e brasileiros e originada no Brasil pela prática de muitos fazendeiros do interior de Minas Gerais, um pactário pode se utilizar de um diabinho chamado Famaliá12 para atingir seus objetivos mundanos. Trata-se de uma prática extraída de um ritual descrito no livro de São Cipriano, em que o então-feiticeiro Cipriano instruía a todo interessado a encontrar um ovo de galo, levá-lo sob o braço a uma encruzilhada, pronunciar algumas palavras a Lúcifer e esperar a eclosão. No

$11 \quad$ Ou seja, a travessia do bem para o mal.

12 Corruptela de [demônio] Familiar. Essa popular lenda folclórica chegou a servir como enredo para a telenovela Renascer (1993), de Benedito Ruy Barbosa. 


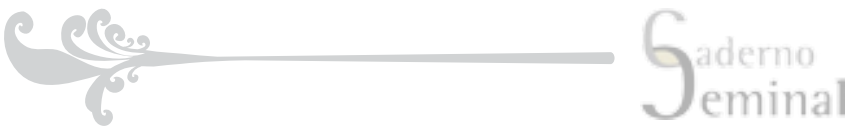

Brasil, apesar de algumas modificações menores, o ritual permanece fiel ao português. O pactário deve manter um relacionamento estreito com a criatura resultante da eclosão, um diabinho, algumas vezes, com forma humana. O dono deve batizá-lo, guardá-lo em uma garrafa, mantê-lo em segredo e alimentá-lo. Todos os pedidos do pactário devem ser dirigidos a essa criatura, que assume o papel de mediador entre seus pedidos e o mundo inferior.

O cavalo Siruiz também erige-se como uma espécie de famaliá, selando o pacto.

Um tal presente tinha de ser para o chefe, fatalmente Zé Bebelo se sentiria ofendido, mas Riobaldo não recusou do presente. Zé Bebelo não passou recibo e elogiou sua nova montaria. [Riobaldo] entregou o cavalo ao Fafafa, para que o cuidasse, retirou-se, dando as costas a Zé Bebelo, sem nenhum receio de levar um tiro nas costas. Nada Ihe aconteceria, porque tinha a proteção do "Drão- o demoninhão (ABEL, 2003, p. 304).

Nesse caso, a escolha do cavalo como aquele que "sela" o pacto de Riobaldo com o Diabo ${ }^{13}$ e, por conseguinte, com seu destino irrefutável, pode ser compreendida a partir da relação desse animal com o mundo das trevas:

Uma crença, que parece estar fixada na memória de todos os povos, associa originalmente o cavalo às trevas do mundo ctoniano, quer ele surja, galopante como o sangue nas veias, das entranhas da terra ou das abissais profundezas do mar. Filho da noite e do mistério, esse cavalo arquetípico é portador de morte e de vida a um só tempo, ligado ao fogo, destruidor e triunfador, como também à água, nutriente e asfixiante. A multiplicidade de suas acepções simbólicas decorre dessa significação complexa das grandes figuras lunares em que a imaginação associa, por analogia, a Terra, em seu papel de Mãe, a Lua, seu luminar, as águas e a sexualidade, o sonho e a divinação, o reino vegetal e sua renovação periódica. (CHEVALIER; GHEERBRANT, 2002, p. 202)

Inúmeros exemplos literários, históricos e religiosos trazem consigo marcas do aspecto sombrio dessa crença com relação ao cavalo e as forcas que ele pode sinalizar. Segundo uma lenda popular da Ásia Central, um herói chamado Töshtük, esposo de Kenjeke, se vê em perigo ao ter sua alma roubada por um cruel feiticeiro. Para recuperá-la, Töshtük precisa cruzar a fronteira entre o mundo dos vivos e o mundo subterrâneo. Ciente dos perigos que seu marido estava prestes a enfrentar, Kenjeke presenteia o herói com um cavalo prodigioso, chamado Tchal-Kuiruk, que é capaz de entender e de conversar com os humanos. No entanto, antes da arriscada viagem, o cavalo mágico afirma que o herói precisará renunciar à sua própria personalidade e confiar em seus poderes sobrenaturais para que sua busca tenha sucesso. Tchal-Kuiruk, então, auxília o herói na procura por sua alma, infiltrando-se no mundo inferior e livrando-o de inimigos.

\footnotetext{
13 O cavalo Siruiz, portanto, é para Riobaldo o que o "cão" de proporções monstruosas Mefistófeles foi para o Fausto de Goethe, ou seja, a reiteração e a chave para o poder, a coragem, o prazer, que são exercidos por ambos os protagonistas através da violência e da crueldade. E do mesmo modo que Riobaldo e Fausto se perdem, tem suas almas salvas ao final de suas travessias. Riobaldo, matando o Hermógenes, sofrendo e expurgando o amor e a morte de Diadorim, largando a vida de jagunço, reencontrando-se com Zé Bebelo, casando-se com Otacília. Fausto, sendo raptado por anjos que surgem e espargem rosas odoríferas de efeito narcotizante, fazendo recuar o demônio.
} 
Assim narra o poema épico quirguiz Er-Töshtük (1885) ${ }^{14}$ e que constitui um exemplo literário e simbólico acerca da natureza não apenas mágica, mas íntima, da relação entre o cavaleiro e seu cavalo. A lenda de Er-Töshtük foi construída oralmente em meio às tradições da Ásia Central, onde a influência do xamanismo se faz intensa. No contexto xamânico, atribui-se ao cavalo poderes sobre-humanos, além da imagem que o animal possui enquanto clarividente, guia, intercessor e familiarizado com as trevas e com o outro mundo.

Ao pano de fundo religioso que ajudou a moldar a alegoria das relações míticas entre o cavalo e o cavaleiro ${ }^{15}$, somam-se outras narrativas históricas e literárias que alargam o simbolismo entorno da natureza dessas mesmas relações. Além de Er-Töshtük, a lenda do cavalo Bayard, iniciada no século XII e, desde então, recorrente em poemas e romances ${ }^{16}$, também trata de um cavalo com poderes sobrenaturais e que se comunica com humanos ${ }^{17}$. No entanto, convém relembrar as mais antigas fábulas em torno do cavalo Bucéfalos, que pertenceu a Alexandre, $O$ Grande. Uma das lendas chega mesmo a afirmar que os poderes de Bucéfalos ultrapassavam os de Pégaso ${ }^{18}$.

Assim, em várias culturas e fábulas inspiradas por crenças e práticas voltadas ao sobrenatural, evidencia-se a ideia de que "corcel e cavaleiro estão intimamente unidos"19 - assim como Riobaldo e Siruiz - e de que o "cavalo instrui o homem, ou seja, a intuição esclarece a razão"20. Essa crença, convém reafirmar, parece ter exercido influência nas lendas e na literatura, como atestam as histórias de Tchal-Kuiruk e Bayard. Trata-se de uma vasta tradição religiosa, lendária e literária a mostrar o quão simbólica e íntima pode ser a relação entre cavaleiro e cavalo; ligação esta que não deve ter passado despercebida por Guimarães Rosa ${ }^{21}$ e que, no universo do sertanejo, não deixa de ser bastante comum.

Desse modo, montando naquele que de imaterial materializou-se, Siruiz, Riobaldo Tatarana assume também seu próprio destino, tornando-se o grande chefe Urutú-Branco. Trata-se da comunhão íntima do homem com aquilo que Ihe foi traçado, sua trajetória, travessia; do "batismo" do cavalo Siruiz e do próprio Riobaldo: "E o velho homem-cujo. Ele entendia de meus dissabores? Eu mesmo era de empréstimo. Demos o demo... E possuía era meu caminho, nos peitos de meu cavalo. Siruiz. Aleluia só" (ROSA, 1986, p. 460).

\footnotetext{
14 Epopéia asiática. É considerada um poema épico folclórico muito popular no grupo étnico dos quirguizes, no Quirguistão.

15 É interessante perceber que a ideia xamânica por trás de Tchal-Kuiruk encontra fundamento similar na tradição do Vodu haitiano, em que a individualidade do praticante — alcunhado de "cavalo" — deve ser abdicada para que a personalidade de um espírito superior — que "cavalga" o praticante — se manifeste.

16 Em poemas com temática de cavalaria de Luigi Pulci e Ludovico Ariosto, e, em tom jocoso, com Chaucer em Troilo e Criseide (1380) e em Contos de Canterbury (1286).

17 Como bem observam Chevalier \& Gheerbrant (2002, p. 205)

$18 \quad$ Um cavalo alado relacionado às virtudes espirituais.

19 Idem, Ibidem, p. 205

20 Idem, Ibidem. p. 205

21 Sabe-se que o escritor possuía vasto conhecimento acerca de práticas religiosas diversas.
} 


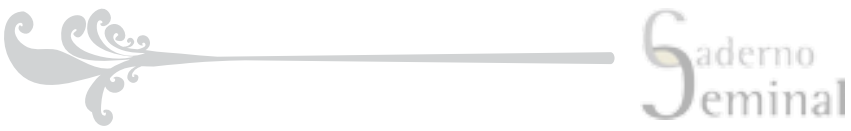

Para Riobaldo, para sempre reverbera aquela canção, certeza de sua predestinação, de que tudo estava escrito: a vida de jagunço, o amor proibido e sem medidas, o pacto, a chefia do bando (reiteração da hybris), a morte de Hermógenes e Diadorim, o abandono da vida de jagunçagem, o reencontro com Zé Bebelo, o casamento com Otacília.

Fui o chefe Urutú-Branco - depois de ser Tatarana e de ter sido o jagunço Riobaldo. Essas coisas larguei, largaram de mim, na remotidão. Hoje eu quero é a fé, mais a bondade... Assim, aquela outra- que o senhor disse: canção de Siruiz- só eu mesmo, meu silêncio, cantava (ROSA, 1986, p. 482).

A canção de Siruiz é tão mágica quanto o cavalo Siruiz, e montar neste último é cavalgar os versos da canção - capaz de percorrer o ar, tal qual Pégaso, e o submundo, tal qual Tchal-Kuiruk — , assumi-los todos para si, embrenhar-se em seus desvios obscuros e em sua energia mágica e oculta. A canção é um cavalo poderoso.

A trajetória do herói está traçada e é impossível fugir dela. Ficam para sempre as neblinas rosianas, as neblinas de Siruiz.

\section{THE MATERIALIZED ECHO: CONSIDERATIONS ABOUT THE PROPHETIC PURPORT OF THE SONG OF SIRUIZ}

Like the mysterious dreams that disturb Joseph son of Jacob in the biblical passage, Guimarães Rosa, in his The Devil to Pay in the Backlands (1956), also "establishes a complete disorder in Riobaldo's heart" (REINALDO, 2005) with a song performed by a faceless and almost absent individual; by an immaterial voice that echoes through the night and pulsates in Riobaldo throughout his entire journey. The song of Siruiz deals with the search for knowledge about oneself and others by means of deciphering a puzzle that includes the "dustnado" of Riobaldo's own existence. When he hears the song, he has his "initiation", he tastes the forbidden fruit and dives into the "backwaters" of the San Francisco river, leaving behind the quiet life in company of his wealthy godfather Selorico Mendes to abandon himself to his destiny and to the adventures of both his henchman life and his forbidden love for Diadorim, the "virgin lady". Riobaldo, then, meanders into the great wild which is the world. His path is traced: a path unknown even to him. He cannot escape from the power of that song and, thus, from his own destiny.

\section{KEYWORDS:}

Guimarães Rosa; song of siruiz; prophecy. 


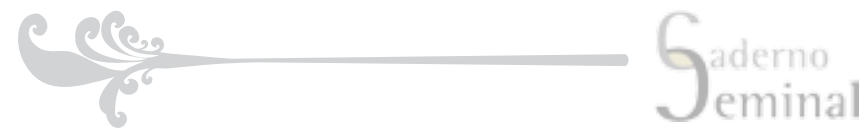

\section{REFERÊNCIAS}

ABEL, Carlos Alberto dos Santos. Rosa autor Riobaldo narrador: veredas da vida e da obra de João Guimarães Rosa. Rio de Janeiro: FAPERJ, 2002.

CHEVALIER, Jean; GHEERBRANT, Alain. Dicionário de Símbolos. 17 ed. Rio de Janeiro: José Olímpio, 2002.

MORAIS, Márcia Marques de. A travessia dos fantasmas: literatura e psicanálise em Grande Sertão: Veredas. Belo Horizonte: Autêntica, 2001. 176 p.

REINALDO, Gabriela. Uma cantiga de se fechar os olhos...: mito e música em Guimarães Rosa. São Paulo: Fapesp, 2005.

A mitopoiesis na canção de Siruiz de Grande Sertão: Veredas. PUC/SP. 1998. Dissertação de Mestrado. Disponível em: <http://www6.ufrgs.br/infotec/ teses97-99/reinaldo-pucsp98.htm >. Acesso em 2 Jan. 2011.

RONCARI, Luiz. A Canção de Siruiz/Ziruis. Disponível em www.ichs.ufop.br/ semanadeletras/viii/arquivos/cfmr/roncari.doc >. Acesso em 15 Out. 2010

ROSA, Guimarães. Grande sertão: veredas. 26. ed. Rio de Janeiro: Nova Fronteira, 1986.

ARAUJO, Heloisa Vilhena de. O espelho: contribuição ao estudo de Guimarães Rosa. São Paulo: Mandarim, 1988.

LAGES, Susana Kampff Lages. João Guimarães Rosa e a saudade. São Paulo: FAPESP, 2002.

LIMA, Deise Dantas. Encenações do Brasil rural em Guimarães Rosa. Niterói: EDUFF, 2000.

MACHADO, Adriana Rodrigues. O mito do pacto em Grande Sertão: Veredas. Revista eletrônica de crítica e teoria de literaturas. Dossiê: oralidade, memória e escrita. PPG-LET- UFRGS- Porto Alegre- Vol. 04 N. 02- jul/dez 2008.

MARTINS, José Maria. Guimarães Rosa: o alquimista do coração. Petrópolis: Vozes, 1994.

ROSENFIELD, Kathrin H. O popular e o erudito: lirismo e reflexão na obra rosiana. Belo Horizonte: Scripta, v. 5, p. 10.

Seminário Internacional Guimarães Rosa (1998: Belo Horizonte). Veredas de Rosa. Belo Horizonte: CESPUC, 2000. 